\title{
Leder
}

\section{Kriser og etikk}

\section{Rune Nydal, Bjorn Myskja og Berge Solberg}

Moderne samfunn synes mer sårbare enn vi synes å like og ta inn over oss. Flere tenkere som Ulrich Beck og Anthony Giddens har påpekt sammenhengen mellom teknologi, kompleksitet og risiko som et særtrekk ved det moderne samfunnet. De teknologier som bidrar til vår velstand og trygghet, er samtidig opphav til nye former for risiko. Vi utsettes dermed for risikoformer som er skapt av en utvikling vi alle har medansvar for, og som ingen enkeltpersoner eller grupper alene kan bære ansvaret for. Det førmoderne livet var farefullt, og samfunnet ble utsatt for alvorlige kriser, men det var en type krise man i mindre grad kunne kalle menneskeskapt og som vi derfor ikke behøvde å laste oss selv og andre for. Noen av de mest alvorlige av vår tids kriser, derimot, er knyttet til våre egne, kollektive handlinger, og det stiller oss overfor spesifikt moderne etiske og politiske utfordringer.

Kriser kan være akutte så vel som kroniske. Blant de siste kan vi regne fattigdomskrisen og miljøkrisen. Det mest nærværende eksemplet på en akutt krise, er fjorårets sammenbrudd i den internasjonale finansverdenen. Den er det direkte bakteppet for dette nummeret av Etikk $i$ praksis. I lys av finanskrisen ønsket vi å invitere til refleksjoner over den moralske lærdom vi kan trekke fra kriser. Kriser og trusselbilder synliggjør og utfordrer betingelsene for våre dagligdagse moralske vurderinger og intuisjoner ettersom kriser oftest handler om et mulig sammenbrudd av tilvante livsvilkår. Temanummerbidragene i dette nummeret fokuserer på analyser av dagligdagse vilkår som kan forstås som årsaker og/eller betingelser for finanskrisen. Bidragene tar for seg forhold som finanssystemets logikk, grenser for økonomenes ansvar og betydningen av tillit eller mistillit mellom yrkesutøvelsen til ulike grupper i samfunnet mer allment. 


\section{Sårbare moderne samfunn}

Forskjellen mellom førmoderne og moderne samfunn er ikke en prinsipiell eller radikal forskjell, ifølge Bruno Latours analyser i boka Vi har aldri vort moderne (1996). Det handler mer om forskjell i form av størrelse, en tilsynelatende liten forskjell som riktignok utgjør en radikal forskjell. Moderne samfunn er effektive fordi handlingene er overindividuelle, de er muliggjort gjennom spesialiseringer og opprettholdelsen av stabile materielle og institusjonelle strukturer. Store dynamiske strukturer gjør det mulig for mennesker å interagere, utveksle ideer, handle og forhandle på tross av store geografiske distanser. Verden blir mindre, og verdens befolkning blir dermed også kollektivt mer avhengig av hverandre.

Enten vi snakker om mulige miljø-, klima-, energi- eller finanskrise handler det om trusler om destabilisering av kollektiver. Dette er kollektiver bestående av institusjoner, materielle og sosiale strukturer som vi ikke bare lever i og tar for gitt, men som også muliggjør eller danner basis for våre daglige handlinger. Våre dagligdagse gjøremål og vurderinger er nettopp dagligdagse fordi de gjentas mer eller mindre ureflektert. Kriser river ned den dagligdagse erfaring gjennom destabilisering eller trussel om en slik destabilisering. Kriser framtvinger refleksjon over våre praksiser og institusjoner, samtidig som de mobiliserer for ekstraordinære tiltak og endringer i disse kollektivene i lys av krisens trusselbilde.

\section{Krise og mobilisering}

Vi har levd med fattigdomskrisen i flere tiår. Til tross for positive endringer i folkerike stater som Kina og India er det mye som tyder på at krisen bare øker. Antall mennesker som lever i overflod i den vestlige verden, er i samme størrelsesorden som det antallet som lever i sult. Fattigdommen er likevel ikke påtrengende, den må stadig oppdages. Kanskje er det fordi den så langt ikke har kraft til å true vårt dagligliv? Det vil innebære radikale endringer å se fattigdommen som en krise, og vi må snarere tvinge oss til å se at det er en permanent krise som vi ifølge moralfilosofer som Thomas Pogge og Peter Singer bærer et ansvar for å opprettholde. Vi må mobilisere moralske ideer og paradigmatiske eksempler for å etablere argumenter for at vår del av verden har et ansvar for fattigdommen, og at det må radikale tiltak til - selv om vår daglige tralt ikke nødvendigvis er truet på måter som framtvinger handling.

Finanskrisen, derimot, mobiliserer. Men som vi har erfart, mobiliserer den ofte i paradoksale retninger, etisk sett. Krisehåndteringen ved finanskrisen er ulik den vi ser ved andre kriser. Miljøkrisen knyttes til menneskeskapte utslipp, og løsningen er å redusere på slike utslipp. Fattigdomskrisen skyldes for liten tilgang på ressurser i deler av verden, og 
løsningen er å øke ressurstilgangen i disse områdene. Finanskrisen skyldes imidlertid at vi bruker mer enn det er ressursmessig grunnlag for i økonomien, og det løser vi ved å bruke enda mer.

Da krisen var et faktum, gikk de fleste statsledere og sentralbanksjefer ut og oppfordret til å øke forbruket for å motvirke finanskrisen. Det ble sagt å være avgjørende å få fart $\mathrm{i}$ hjulene så raskt som mulig igjen. Vi må bare ikke opptre som om det er krise - da forsterker vi den. Glem miljø-, energi- og klimakrise, i det minste for en stund. Når vi har hjulene skikkelig i gang igjen, kan vi bruke overskuddet til å takle neste krise. Bruk mer, kast mer, støtt industrien, ja, endatil bilindustrien om du må - bare du ikke tror det er en krise på gang, løser dette seg av seg selv. Ned med renta, opp med forbruket. Den kollektive krisebevissthet er den store trussel. Mange, kanskje de fleste av de som hadde det bra fra før, har dermed foreløpig forbedret sin privatøkonomi i kriseperioden gjennom rekordlav rente.

Store offentlige ressurser ble også satt inn av myndigheter verden over, myndigheter som også har måttet revurdere sin økonomiske politikk i lys av denne krisen. Vi står i fare for å opprettholde en problematisk økonomisk logikk gjennom tiltak som settes inn for å motvirke krisen. Dersom Rune Skarsteins analyser i dette nummeret er riktig, vil det periodevis måtte framtvinges en kritisk ubalanse i store økonomiske systemer som drives av profittmaksimering. Flere spør om krisetiltakene vi har sett, ikke vil forsterke risikoviljen ettersom myndigheter verden over har demonstrert sin vilje til å redde skakkjørte bedrifter. Bare man er stor nok, vil det stå for mye på spill.

Island har blitt et symbol på krisen. Det skyldes i stor grad den eksepsjonelt store betydningen finanssektoren fikk for islandsk økonomi i løpet av en drøy tiårs periode. Men en skal huske at det er en rekke land i verden som trolig er blitt langt hardere rammet av finanskrisen enn Island, som også har et solid ressursgrunnlag og en høyt utdannet befolkning. Dette er avgjørende for raskt å komme ut av krisen. De som rammes hardest, er igjen de fattigste - denne gangen ikke av våre daglige handlingsmønster, men av vår krisehåndterende handlingsrespons.

Det er ikke nødvendigvis slik at vårt daglige handlingsmønster, etiske blikk og engasjement blir skjerpet gjennom kriser. Tvert imot - de som er seg selv nærmest, blir om mulig enda mer nærsynt. Vi må nesten bare håpe at krisens virkninger kan nærmest av seg selv trekke i rett retning. Vi kan håpe på heldige sammentreff mellom krisehåndtering og bærekraft, rettferdighet, moralsk mobilisering og skarpsyn. Men uansett er kriser en god anledning for å reflektere over de samfunn vi har bygget, og hvor gode og rettferdige våre institusjoner er. Vi håper at dette temanummeret skal kunne gi noen innspill for en slik refleksiv aktivitet. 


\section{Krisens mekanismer og okonomenes ansvar}

Rune Skarstein analyserer i artikkelen «Finanskrisas bakgrunn» hvordan det kapitalistiske systemet i seg selv belønner og hedrer grådighet. Det er imidlertid ikke de umoralsk grådige aktørene, de som bryter det økonomiske systemets regler, slik som Bernhard Madoff, som kan forklare hvorfor vi får sammenbrudd i systemet. Grådigheten er innebygget i systemet som del av dets grunnleggende logikk, og dreier seg dermed ikke om den enkelte aktørens moralske karakter. Men disse økonomiske forbryterne kan kanskje fungere som en slags symptom på de vekstdrivkreftene som bringer oss inn i de økonomiske krisene med kortere eller lengre mellomrom. I faser der økonomien vokser raskt, vil det være behov for å utvide rommet av mulige profitable pengeplasseringer. Disse utvikles utenfor produksjonsøkonomien fordi denne sektoren rommer muligheter for høsting av raske gevinster. En finanssektor fristilt fra produksjonen, har muligheter for å vokse raskt, og dermed også trekke til seg stadig større investeringer.

Det er flere trekk ved vår tid som gjør at denne utviklingen forsterkes og trekker inn langt flere enn tidligere tiders lignende finansvekst. De svært effektive elektroniske mulighetene for handel med verdipapirer kombinert med økonomisk liberalisme og globalisering, fører til at prosessene akselererer og internasjonaliseres. Slik kan islandske fiskere og bønder gjøres ansvarlig for bankkollapser i Nederland og Storbritannia, og små norske kraftkommuner tape langt mer enn det de eier på en altfor lånevillig amerikansk banksektor.

Dagfinn Dybvig diskuterer i artikkelen «Farlige forbindelser? En refleksjon over forholdet mellom teori, praksis og moralsk ansvarlighet i økonomifaget» samfunnsøkonomenes moralske ansvar for krisen. Han hevder at samfunnsøkonomien som fag inntar en vanskelig posisjon mellom teori og praksis. Denne posisjonen innebærer at økonomene ikke bare har en vitenskapelig rolle, men at de bærer et moralsk ansvar for hvordan faget direkte og indirekte legger premisser for økonomisk politikk. Dybvig argumenterer for at en profesjonsetisk refleksjon over samfunnsøkonomiens rolle og betydning er nødvendig, og han foreslår derfor blant annet en samfunnsøkonomiens «vær-varsom-plakat» etter mønster av journalistikkfagets etiske egenkontroll. Dybvigs konklusjon er at samfunnsøkonomene sviktet sitt folkeopplysende mandat forut for krisen.

I artikkelen «Self-interest, deregulation and trust» tar Salvör Nordal utgangspunkt i den dramatiske islandske erfaringen av hendelsene som fulgte da den kunstig oppblåste finanssektoren sprakk. Island er fortsatt i en usikker situasjon, der de ennå ikke vet om de får lån og hvor harde betingelser som vil knytte seg til disse lånene. De foretar også et oppryddingsarbeid i form av undersøkelseskommisjoner som skal gjøre rede for hva som faktisk skjedde da landets økonomi kollapset. Nordal påpeker at de landene som er hardest rammet av finanskrisen, er land der den nyliberalistiske 
politikken har hatt sterkest grep. Hun knytter følgelig sin analyse til det ideologiske grunnlaget for denne økonomiske politikken, representert ved Milton Friedmans argument for at bedrifters eneste sosiale ansvar er å maksimere eiernes profitt. Nordal ser finanskrisen også som en politisk og moralsk krise, ettersom samfunnet ikke sørget for å legge tilstrekkelig bånd på menneskets egoistiske impulser, samtidig som finanssektoren selv ikke viste seg tilliten verdig. Tillit undergraves når grunnleggende samfunnsordninger som finansvirksomheten har egeninteressen som sitt eneste og grunnleggende etiske prinsipp, og tillit er det moderne samfunnets lim.

\section{Åpen del: Lovregulering av assistert befruktning og rettferdig stoy}

Fra finanskrisen går vi i den åpne delen over til en påstått verdikrise knyttet til familieinstitusjonen i moderne samfunn. Norge har fått en ny ekteskapslov samt adgang til assistert befruktning for lesbiske. Ifølge kritikerne har endringene kommet altfor raskt, og den offentlige diskusjonen har kommet i ettertid. Mange har stilt spørsmål ved om adgangen til å lage barn med assistert befruktning for lesbiske par er forenlig med hensynet til barnets beste, som er nedfelt i den norske bioteknologiloven.

I sin artikkel «På sviktende kunnskapsgrunnlag? Assistert befruktning for lesbiske par» sier Sigrun Saur Stiklestad seg enig i deler av denne kritikken. Utredningsarbeidet forut for å gi lesbiske adgang til assistert befruktning var langt spinklere i Norge enn det for eksempel var i Sverige for noen år tilbake. I Norge ble det ikke gjennomført noen betydelig gjennomgang av den forskningsmessige statusen på området. Ifølge Stiklestad er dette beklagelig - ikke fordi lovendringen vil bidra til ulykkelige barn og familier, men fordi det finnes en solid forskningslitteratur som kunne ha blitt lagt til grunn. Denne forskningen konkluderer med at barnets beste er i varetatt i planlagte lesbiske familier. Mangelen på interesse for å basere politikken på forskningsbasert innsikt, gjorde beslutningen om å la lesbiske få adgang til assistert befruktning langt mindre robust i den norske befolkningen enn den kunne ha vært. Kritikerne som argumenterte for at homofiles rettigheter ble satt høyere enn hensynet til barnets beste, fikk lett spill.

Den andre artikkelen i den åpne seksjonen er Paul Voice sin artikkel «Unjust noice», som handler om støy som en betydningsfull kilde til skade. De som utsettes for støy, er ikke bare uheldige, i mange tilfeller utsettes de simpelthen for en urett. Et eksempel kan være privatfester i tettbygde nabolag uten forvarsel, sent på natten før en arbeidsdag. Det er en privat aktivitet som ikke er samfunnsmessig nødvendig, og den framstår som en urimelig belastning. Voice påpeker at filosofer stort sett har behandlet støy gjennom slike eksempler, og han nevner Schopenhauers klage over høylydt bruk av 
pisker. Vi kan legge til Kants klage over salmesangens påtrengende og larmende karakter som tvinger folk til å innstille sin tankevirksomhet. Et hovedpoeng for Voice er at noen former for støy er ikke bare plagsomme og forstyrrende, men må behandles som tilfeller av sosial urettferdighet. I mange tilfeller er nemlig støy, som annen forurensning, en følge av mer eller mindre nødvendig aktivitet. Støy må i disse tilfellene forstås som en uunngåelig byrde som fordeler seg ulikt blant samfunnsborgerne. Støy blir dermed et spørsmål om fordelingsrettferdighet, ettersom det er en belastning som følger av sosialt samarbeid. Voice velger her å følge en liberalistisk tilnærming til rettferdighet slik den er utviklet av John Rawls, heller enn det utilitaristiske alternativet. Gitt dette rammeverket, argumenterer han for at noen former for støy utgjør en rettferdig belastning ettersom de er en følge av rimelige aktiviteter.

\section{Bokanmeldelse: Hva er tillit?}

Etikk i praksis ønsker å rette oppmerksomheten mot faglitteraturen innen anvendt etikk på skandinaviske språk gjennom å publisere bokanmeldelser. Først ut er Trond Åms anmeldelse av Harald Grimens bok Hva er tillit? (2009) som er utgitt i Universitetsforlagets serie med korte introduksjoner til viktige fagfelt. 